\title{
Landbevæbningen på Als under Treårskrigen
}

\author{
Af Ernst Christensen.
}

Jo ældre folk bliver, jo større plads indtager minderne i deres tankeverden. Sådan var det også for min oldemor, min fars farmor, der var født 1813. Sine sidste år, hun døde 1904, henlevede hun $i$ mindernes verden. Når jeg søgte ind $i$ hendes stue for at læse lektier - tyske lektier, - spurgte hun bekymret, om jeg nu også tænkte på tysk. Det var nok dette, der gav anledning til, at hun begyndte at fortælle om sin ungdom, om krigene, og helst om Treårskrigen - om hvordan hun som ung kone på gården havde måttet sørge for de mange indkvarteringer, om hvordan man med angst og bæven havde hørt kanonerne tordne på Sundeved, og bare det med kanonerne var nok til at sætte en lille drengs fantasi i bevægelse - en efterladt dragonsabel og et gammelt forladegevær gjorde også sit. $\mathrm{Og}$ sådan gik det til, at jeg slog rod i historien.

Den tid blev levende for mig igen, da jeg som ung mand, $i$ min kones hjem, læste en dagbog ført af hendes oldefar - den er benyttet her som en værdifuld kilde - og den dvælede navnlig ved begivenhederne omkring Treårskrigen. Senere fik jeg lyst til at finde til bunds $i$, hvordan alsingerne havde levet $i$ de bevagede år omkring 1848.

Ser man nøjere til, er der to slags alsinger. Der er de nørherreds, der allerede havde været frie bønder under kongen i mange år - de er ligesom mere frigjorte og selvstændige - mere djærve og selvsikre end de sønderherreds, eller rettere de fra den hertugelige del af Sønderherred, som indtil 1851 var hoveripligtige til hertugens godser. Samtidig med, at de ofte måtte >allernådigst c ansøge hertugen om visse dispositioner, måtte de hævde deres rettigheder, så de ikke blev gået for nær af den noget despotiske hertug Christian August. Selv om de okonomiske forhold ikke var meget anderledes i Nør- end i Sønderherred, havde de før 
nævnte forhold alligevel givet dem et noget forskelligt præg. Men da oprøret brød ud i 1848, stod de enigt sammen.

Hertugen havde naturligvis også sine tilhængere. Det var folk, som han havde vundet, ved sin charme, ved løfter og smiger ved fælles interesse for hesteavl mere end ved sin politiske virksomhed. Hesteavlen spiller mærkværdigvis en stor rolle. Hertugens stutteri var kendt over hele Europa, og han havde et meget udbredt samarbejde med bønderne på hesteavlens område, også med de nørherreds, så også her havde han sine tilhængere. Jeg har tidligere skildret, ${ }^{1}$ hvordan han ved valget til stænderforsamlingerne søgte at ove et vist tryk på sine bønder for at få dem til at stemme på sine tilhængere, og hvordan det i første omgang mislykkedes, mens det $i$ anden omgang lykkes at få herredsfoged dr. Steffens fra Nørborg valgt. Dog kun denne ene gang. Ved valget $i 1847$ vælges en bonde, H. C. Bladt fra Tandsgaard. Hertugens politiske virksomhed er nu så åbenlys og hensigten så klar, at bønderne kommer i skarp opposition til ham. De kender ham personligt, - de ved, at der under hans personlige charme skjuler sig noget af en despot, de vil nødigt se ham som deres landsherre $i$ et selvstændigt Slesvig-Holsten. Derfor reagerer de voldsomt $i$ de bevægede martsdage 1848.

Men var bønderne kongetro, så var embedsmændene i administrationen det så sandelig ikke. Med en ganske enkelt undtagelse var de tysksindede. Hertug Christian August havde forstået at få sine folk anbragt, ikke blot $i$ sin egen del af øen, men også $i$ Sønderborg by og Als Nørherred. Trods sit modsætningsforhold til kongen må han have haft en vis indflydelse $i$ :Det tyske Kancelli «, for mange af embedsmændene skyldte hertugens nåde deres embede, og de nød godt af hans gæstfrihed på Augustenborg slot. Derfor tog de let på deres embedsed til kongen og havde gerne fulgt hertugen, da oprøret kom.

Den 21. marts 1848 forlod hertug Christian August slottet $i$ Augustenborg, og et par dage efter rejste hertuginden og deres børn. Hertugen tog efter en forhandling med sin broder, prins Frederik af Nør, til Berlin for at bede om støtte hos kong Friedrich Wilhelm af Preussen.

Den 23. marts dannede prinsen af Nør den provisoriske regering for Slesvig og Holsten, efter at Danmark havde afslået kra- 
ret om en fri forfatning for hertugdømmerne samt en optagelse i det tyske forbund.

En af de første handlinger, den provisoriske regering foretog sig, var at meddele embedsmændene, at de kunne forblive $i$ deres embeder, men at de, der havde kasser under sig, måtte indsende meddelelse om beløbet til den nye regering og virke for indkaldelse af det værnepligtige mandskab. Og embedsmændene på Als havde sikkert gerne fulgt denne opfordring, hvis folkestemningen ikke havde været så truende, at de simpelthen ikke turde følge oprørsregeringens direktiver. Lørdag den 25. marts kommer de første efterretninger om oprørets udbrud til Als. De fleste får det dog først at vide om søndagen ved kirken. Der går rygter om, at regulært militær og friskarer er på vej mod nord, og uro og forvirring breder sig blandt befolkningen. Der fandtes ikke en eneste soldat under kommando til at afværge et angreb på øen. Folk kom sammen i landsbyerne for at drøfte situationen, og mange talte om at bevæbne sig. Forbitrelsen mod hertugen var stor, og alle tyske sympatier blev fejet til side.

Ved en forsamling i Guderup meddelte Christian Klyhn, at han var en dansk mand. Han bad andre saf samme sind " om at følge med ind $i$ en anden stue. De fulgte ham alle, til sidst også synsmand Frederik Jepsen, der var en ivrig slesvig-holstener.' I Mels havde bønderne ved efterretningen om oprøret fundet sammen på deres, sædvanlige samlingssted i smedien. Her var stovte _og selvbevidste mænd som Henrik Eriksen, Jørgen Rasmussen og mange andre, og de var meget harmfulde over de Nørborg-embedsmænds lunkne holdning. I samtalens løb er der så en, der får en lys tanke: Hvad om vi tog ind og snakkede fornuft med dem! Og som sagt så gjort. Man fik samlet en hel skare fra Mels og andre byer sammen, og $i$ et helt folketog vandrede man til Nørborg. Først til herredsfoged Steffens. Steffens bley bange og lod døren låse - han var ikke hjemme, lod han meddele. Så fortsatte man til amtmand Johannsen, som boede på Druelund. Her var man mere heldig, man traf amtmanden, og så måtte han stå skoleret for bønderne, der eksaminerede ham $i$, hvordan en dansk embedsmand havde at opføre sig.

Mandag den 27. marts blev der så afholdt et møde ved Melsgaards molle. Embedsmændene havde fảet en ret truende indbydelse og var da også kommet til stede. Her talte krigsråd Rie- 
gels fra Fægteborg. Han var husfoged på Nørborg og den eneste virkeligt dansksindede embedsmand på øen, og her talte Henrik Eriksen og mange andre fremtrædende bønder, og de skånede ikke embedsmændene. Da disse så blev fornærmede og spillede forargede og spurgte, hvad meningen var, sprang skipper Christen Hansen fra Nørborg op og råbte: 'Ja, vi ved nok, at her er fuldt af øglereder, men nu skal det være slut! I dag skal reden tages ud og ynglen ødelægges! ${ }^{8}$ Sådanne og lignende udtalelser måtte øvrigheden tage imod, og $\mathrm{da}$ de ved afslutningen blev spurgt, om de ville forblive kongen tro, turde de ikke andet end give deres løfte. Denne resolutte optræden af de Nørherreds bønder havde den virkning, at øvrigheden i Nørborg blev hindret i at anerkende den provisoriske regering.

I Sønderborg var embedsmændenes holdning lige så usikker.

Allerede søndag den 26. marts holdtes det første møde på rådhuset for at afgøre, om man skulle anerkende oprørsregeringen. Tyskerne med borgmester Langreuter i spidsen talte meget begejstrede for, og danskerne med købmand Hanssen Norsk som ordfører lige så ivrigt imod. På et andet møde dagen efter kom man heller ikke til noget resultat, og et tredie blev ansat til tirsdag den 28. Dette møde blev ikke afholdt, for det danske krigsskib s Najaden" kom den dag til Sønderborg, og så var al vaklen forbi. Det var et stort held, for de alsiske bønder havde lovet øvrighedspersonerne, sat hvis de sluttede sig til oprørerne, ville deres blod komme til at flyde $i$ rendestenen ${ }^{4}{ }^{4} I$ alle beretninger om disse dage afspejler sig vel alsingernes uro og bekymring, men tillige deres faste holdning. Overalt kommer de sammen og drøfter begivenhederne, og overalt tales der om våben. Ingen af de civile embedsmænd har man tillid til, men betragter dem nærmest som forrædere. Biskop Jørgen Hansen, der er en ægte søn af folket - smedesøn fra Tandslet, - udtrykker det sådan: sGud bevare os for en tid, da folket må føle sig opfordret til at minde øvrigheden om sin pligt, mens det omvendte er i sin orden!

Under hele denne forvirring levede man i bestandig frygt og ængstelse for, at oprørernes friskarer skulle komme til øen derfor befolkningens iver efter at væbne sig.

Endelig skete der noget, der skabte ro i sindet og orden i forholdene.

Den 27. marts var korvetten >Najaden « på slæb efter damp- 


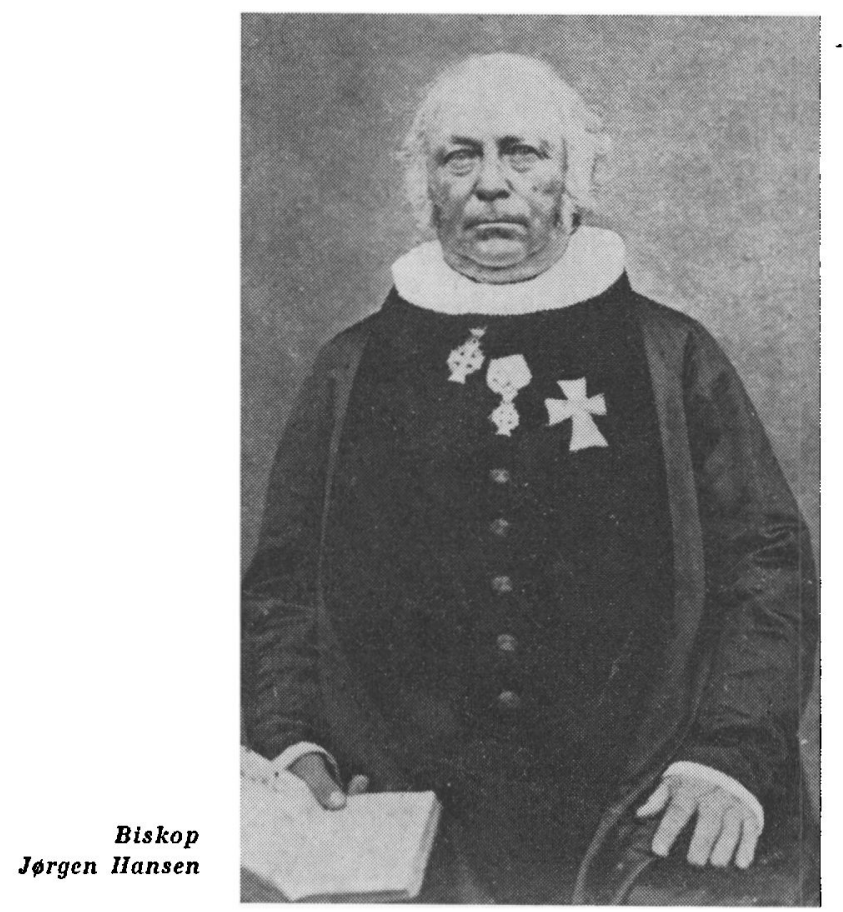

skibet > Geysir " ankret op ved Kegnæs. Knapt havde man inde på land fået øje på skibet med det danske orlogsflag, før en bonde fra Skovby, Christen Petersen, lod sig ro ud til korvetten. Han fortalte kaptajnen, Dirckinck Holmfeld, om de spændte forhold på Als, om uroen og bekymringen for, at øen skulle blive taget af insurgenterne, inden der kom hjælp. Kaptajnen må åbenbart have fundet behag i denne jævne mand og hans beretning, for han bad ham blive om bord og gøre ham selskab på rejsen til Sønderborg. Selv satte han sig straks til at skrive et kort brev til biskop Hansen, hvem han havde fået udpeget som en mand, man kunne stole på, og hvori han forsikrede, at land- og søstridskræfter ville blive sat ind for at forsvare øen, og at der fra nu af herskede krigstilstand, og han bad om, at befolkningen ikke ville gøre skade på hertugens ejendom. Dette brev sendtes med båden iland - uden adresse, for at det ikke skulle falde $i$ forkerte hænder, og bådens ejer blev bedt om at aflevere det til pastor Hen- 
ningsen i Lysabịld, der så skulle sende det videre hurtigst muligt til biskop Hansen. Fra Lysabild præstegård blev der så sendt ridende bud til Guderţ̣ præstegård: "

Biskoppen havide netop haft besgg af krigsråd Riegels fra Nørborg, og de havdê drøftet oprettelsen af en folkevæbning. Riegels var gået til Egen by for at tale med andre om samme emne, da en ryttep kom "spræungendê ind $i$ præstegården på en skummende hest og afleverede brevet fra kaptajn Dirckinck Holmfeld. Biskoppen "sendér.'forst sine kônfịmander hjem med budskab om, at der er hjælp undervejs, ø̂g-iler så ud for at søge efter Riegels, men finder ham ikke. Så opsætter han i hast nogle proklamationer, som sendes til Nørborg og Ketting. Imens lader han spænde for og sætter sig, glad i sindet, men svedig og forpustet, på vognen for at lade sig køre til Sønderborg og om muligt træffe kaptajn Dirckinck Holmfeld.

Efterrefhingen om $>$ Najadens * ankomst er nu gået som en løbejild ud over øen, og vejen er fuld af folk, som alle iler mod Sønderborg. Lige udenfor byen, ved møllen, mødte biskop Hansen kaptajnen, -som var på vej mod Guderup. Han kom over på biskoppens vogn, og de vendte om. På køreturen tilbage standsede de flere gange, fordi kaptajnen gerne ville høre, hvordan stemningen var. Nogle mænd til hest spurgte, om han, der var skyld i dette (hertugen), kunne komme tilbage hertil igen. Kaptajnen svarede, at det håbede han da ikke, og så råbte man hurra og svingede med hatten. Dirckinck Holmfeld spiste til middag hos biskoppen og blev derefter kørt tilbage til Sønderborg.

Var stemningen høj ude på øen, så var den det ikke mindre $\mathbf{i}$ Sønderborg by. En sumådelig menneskemængde ${ }^{8}$ var taget ind til byen for at hore, hvad ovrigheden og magistraten ville beslutte på det tredie møde, som skulle afgøre, om byen ville tilslutte sig den provisoriske regering, og her ville bønderne også have et ord med i laget. Heldigvis for de tysksindede fik man andet at tænke på. Vel samledes magistraten i rådhuset, men Langreuter erklærede, at man nu var i fjendens vold, og ville nedlægge sit embede. Noget egentligt borgermøde blev der ikke afholdt, men folk fik alligevel nok at beskæftige sig med.

Først var der en hestetransport, som fra de hertugelige stutterier skulle sendes til oprorshæren. Borgmester Langreuter ville ikke hindre det, mien folket tog sagen i sin egen hånd og sendte 
hestene tilbage, hvor de kom fra. På samme måde gik det med nogle vogne af hertugens, hvori bl. a. befandt sig hertugens hofråd Barth. Også de blev sendt tilbage til Augustenborg.

Og så kom »Najaden «! Da den rundede pynten ved slottet, hejste lodsoldermanden efter befaling fra Hanssen Norsk Dannebrog ved indsejlingen til Sønderborg, og folkeskaren strømmede ned lid. Kaptajn Dirckinck Holmfeld holdt tale til forsamlingen og havde nu vendt sig fra tvivI og modløshed til fortrøstning og tillid. Kaptajn Dirckinck Holmfeld holdt tale til forsamlingen og spurgte, om den ville være Danmarks konge tro og erklære den provisoriske regering krig. Folkeskaren råbte ja, ja! og hurraråb for kongen rungede ud over havnen og byen. Efter alle de beretninger, der foreligger om begivenhederne $i$ disse dage, og de er næsten nøjagtigt samstemmende, må det have været en af de helt store dage $\mathrm{i}$ byens historie. Der skete ingen alvorlige overgreb mod de tysksindede, og der kom ikke til sat flyde blod c. Kaptajn Dirckinck Holmfelds ordrer blev fulgt til punkt og prikke. Han nød en uindskrænket tillid og hengivenhed blandt befolkningen. Det var sikkert også hans autoritet, der gjorde, at intet alvorligt skete på Augustenborg slot dagen efter, den 29. marts.

Da samledes en stor skare bønder - de fleste var fra Sønderherred - ved slottet. Ingen lod sig se. Man vidste jo, at hertugen og hans familie var rejst. Men hofråderne Barth og Prehn måtte da være der, eftersom deres afrejse var forhindret dagen før. Man råbte på dem og blev temmelig nærgående, og endelig kom så hofråd Barth frem på slotstrappen. Han havde ikke sit ridderkors(!) på, og bønderne råbte til ham: sHar kongen ikke givet dig et dannebrogskors, vel do tej dit Dannebrog o *! Og Barth måtte pænt hente sit ridderkors og tage det på.

Men nu forlangte folkeskaren, at han skulle hejse et dannebrogsflag på slottets flagstang. $\mathrm{Og}$ så kom Barth igen $\mathrm{i}$ knibe, for der fandtes ikke et dannebrogsflag på slottet.

Der blev så sendt et ridende bud til præsten Krogh-Meyer i Ulkebøl for at låne hans. Barth måtte hejse det på kuplen over slottets port, og det blev hilst af mængden med begejstring og svingen med huer og hatte. Dog ikke af Barth. Han så sur ud og stirrede mod jorden. Men det passede ikke bonderne. ,Vil du se op til Dannebrog og råbe hurra!e råbte skaren truende. Og Barth måtte pænt parere ordre. Barth blev dagens syndebuk, men sam- 
me skæbne var iøvrigt tiltænkt de andre medlemmer af hertugens hofstab, Behn, Renter og navnlig hertugens hestehandler eller hestesagkyndige, Fischer, som man på grund af hans optræden kaldte for sbaron * Fischer, men de erklærede sig for syge. Man ville hente dem, men morkningen kom, og der var alvorligere ting at tænke på. Man skulle nemlig have lagt beslag på hertugens våben. Hertugens rustkammer blev bevogtet af hans jægere, men de blev fjernet og døren brudt op. Stæenderdeputeret H. C. Bladt fra Tandsgård og et par synsmænd fra Sønderherred optog en fortegnelse over våbenlageret, og det blev overdraget til løjtnant, toldkontrollør Runacker fra Fynshav, der af Dirckinck Holmfeld havde fået fuldmagt til at beslaglægge dem. De blev stående på slottet til dagen efter mod, at Barth indestod for dem

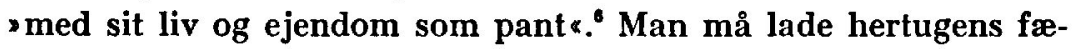
stebønder, at det var en billig hævn, de tog for de mange ydmygelser, de havde lidt under det forhadte hoveri - for dette evindelige kryberi med hatten $i$ hånden, når de ville opnå noget hos hertugen og hans lakajer.

Den 28. marts udsendte kongen følgende opråb:

Trofaste danske mænd!

I denne Farens Stund har det dybt rørt mit Hjerte, at I glemmer Eder selv, og kun erindre Eders Konge og Eders Fædreland.

Alle Vegne fra indstrømmer Udtryk af urokkelig Hengivenhed og Tilbud om de største Opofrelser. Det er mit Hjertes Trang og min kongelige Pligt at lade et Svar udgaa til mit Folk.

Danner, saa vidt det staa til Eder, ved egne Midler frivillige bevæbnede Corps, der slutte sig til min Hær, under den militære Commando.

Mange have gjort et saadant Tilbud, efterfølger deres Exempel. Eders Iver for at uddanne Eder til Fædrelandets Forsvarere skal jeg imødegaa ved, saasnart som muligt, at sende Eder kyndige Befalingsmænd. Stiller Eder Alle som Een under mit, under Fædrelandets Banner.

Alles Iver styrke Alles Sammenhold, og, om Gud vil, skal 
Lovligheden besejre Oprøret og føre Fædrelandet til Fred, Frihed og Ere.

Christiansborg Slot, den 28. Marts.

Frederik $R$.

A. W. Moltke.

Dette opråb kom med krigsskibene til Sønderborg. Imidlertid havde krigsråd og husfoged Riegels på Fægteborg sammen med flere andre gjort et stort arbejde for at få dannet en kystbevogtning, og ved den begejstrede modtagelse af $>$ Najaden i Sønderborg havde flere af øens mænd besluttet at oprette en landbevæbning. Det er nok dette, der har ansporet til følgende opråb:

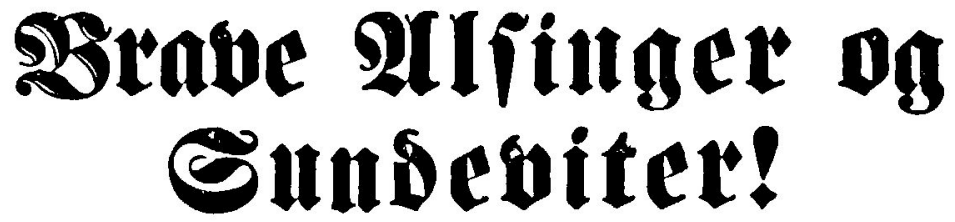

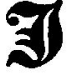

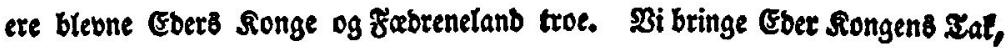
Fabelanbets og Ebers banfle \$lebborgereb \$elfignelfe berfor. - \$ bave for= langt Wjelp mod Lanbets Fienber. - Saa burtigt fom muligt ere vi ilebe tit

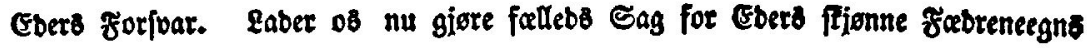

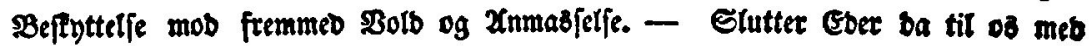
Raab og Daab og vabner Eder XUle fom Een - ville $\mathbf{3}$ trabe $i$ bore Fialler,

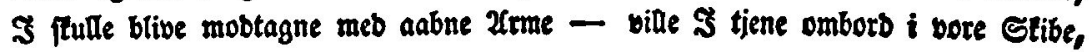
Danmatls gamle Flag flal bejtytte Eber. -

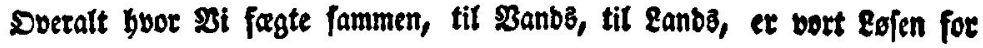
Songe, zabrenetanb og zEren. -

Sampiribet IIelia, ben 30 se stats 1848. M. IIaxthausen. Steen-Bine.

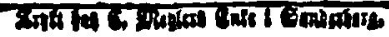

Affotograferet pd Sønderborg slot

Samme dag, som dette opråb blev udsendt, samledes alle våbendygtige mænd ved Majbøl kro. Det blev her besluttet at oprette 
en landbevæbning under løjtnant Runackers kommando. Løjtnant Runacker var, som allerede nævnt, toldkontrollør og boede i kontrollørboligen i Fynshav — hans far var indvandret fra Tyskland, hvor han først havde været munk, men havde forladt klostret og var flygtet nordpå, og senere var han gået $i$ dansk tjeneste, ligesom hans søn efter ham.

Runacker udnævnede nu alle de mænd, der havde været inde som soldat, til underofficerer, og de kom straks $i$ arbejde med at optage en fortegnelse over de frivillige i korpset. Disse lister blev indleveret til Runacker inden middag den 31. marts.

Allerede samme dag blev landbevæbningen alarmeret. Et fjendtligt skib havde krydset rundt inde under østkysten af øen, og man ventede, at det ville sætte tropper $i$ land ved mørkningstid. Hele mandskabet kom i th fart på benene bevæbnet med, hvad de i hast kunnę få fat på af skarpe våben, og trąk ned til stranden. Imidlertid sejlede skibet med kưrs mod Fyn, og der blev ingen landgang på Als.

Den 1. april fik Als en kommandant, H. C. Riegels. Et opråb, han udsendte ved sin tiltrædelse, siger en del om hans tidligere labebane og hans forhold til alsingerne:

Mine kære og prøvede Landsmænd paa Als.

De fleste af Eder kender mig, thi med mange af Eder er jeg opvokset, og mange af Eder har tjent under mig. Ja, en Del af Eder har i Felttoget 1813 delt Farer og Byrder med mig! Overalt hørte vi kun Ere og Ros, thi vi havde kun Pligt og Troskab for $\emptyset$ je.

Da jeg som Slesviger meldte mig til Tjeneste for at værne om den Kongelige Gave, der gør Slesvig til et selvstændigt Hertugdømme, da har Kongen skuet mig i Hjertet, idet Hans Majestæt har udnævnt mig til Kommandant over Als.

Det er nu 41 Aar siden jeg som 15 aarig Frikorporal vendte hjem fra Kjøbenhavns Belejring og første Gang meldte mig til min Faders Tjeneste. Meget har siden den Gang forandret sig, men Alsingernes Troskab er uforandret. Dette har vi vist hinanden, hvor vi mødtes, og dette vil vi igjen vise hinanden, idet jeg herved opfordrer enhver tro Alsinger til at slutte sig til mig, og følge mig, for at værne om vor Sikkerhed og Ejendom. Fuld af Tillid til alle tro Mand i Slesvig tilraaber Kongen 
os Slesvigere: "I ville ikke bortkaste Lovlighedens og Frihedens Velsignelser for at tjene Frgjerrrighedens troløse Planer *.

Nej, brave Alsingere, dette ville I ligelidt nu, som I hidtil har villet det. Vi ville vise andre tro Slesvigere, at Enighed gør stærk, og vi ville stole paa, at Gud er med den retfærdige Sag.

Jeg opfordrer derfor alt ungt og vaabendygtigt Mandskab til ikke længere at skjule Geværerne, men nu komme frem og bruge dem!

Fornemmelig opfordrer jeg alle mine gamle Regimentskammerater til at samles om mig, til Hest eller til Fods, og væbnet saa godt som muligt, for at bruges som Underbefalingsmænd.

Ved Egen Kirke onsker jeg at samles med Eder mine brave Alsingere. Søndag den 2. April om Middagen Kl. 12, til hvilken Forsamling jeg navnlig indbyder de Herrer Sognepræster, den Embedsstand, der formentlig paa Als blev Pligt og Ære tro.

Jeg vil meddele Eder, hvorledes vi bedst kan bidrage til at forsvare vort kære Als, og jeg venter, at I med Lyst og Mod forbereder Eder dertil, thi vel ved jeg, at Viljen er god, men denne er ikke tilstrækkelig; der udkræves ogsaa Dygtighed, fremfor alt Sammenhold!

Altsaa vi sees den 2. April!

Sønderborg, den 31. 3. 1848.

\section{H. C. Riegels}

Kommandant paa Als.

Dette opråb blev bekendtgjort i ’Den danske Slesviger «. Mødet ved Egen kirke satte yderligere fart i tilstrømningen af frivillige til landbevæbningen. Der nævnes de første dage 1500 i Nørherred og 2000 i Sønderherred. Imidlertid er disse styrker vel reduceret en del ved indkaldelse til hæren, men tilbage stod en anselig styrke. Som næunt i Riegels opråb bestod den både af kavalleri og infanteri.

Landbevæbningen var udrustet dels med geværer, deriblandt dem, der var fundet på Augustenborg slot og allerede dagen efter uddelt til de frivillige, dels med spyd og lanser.

De fleste var hjemmesmedede, og smedene havde $i$ de dage mere travlt med at smede våben end at hvæsse plovjern, og der blev lagt megen opfindsomhed og snilde for dagen - det gjaldt om at .finde en type, der kunne gå godt $i$ bund! 

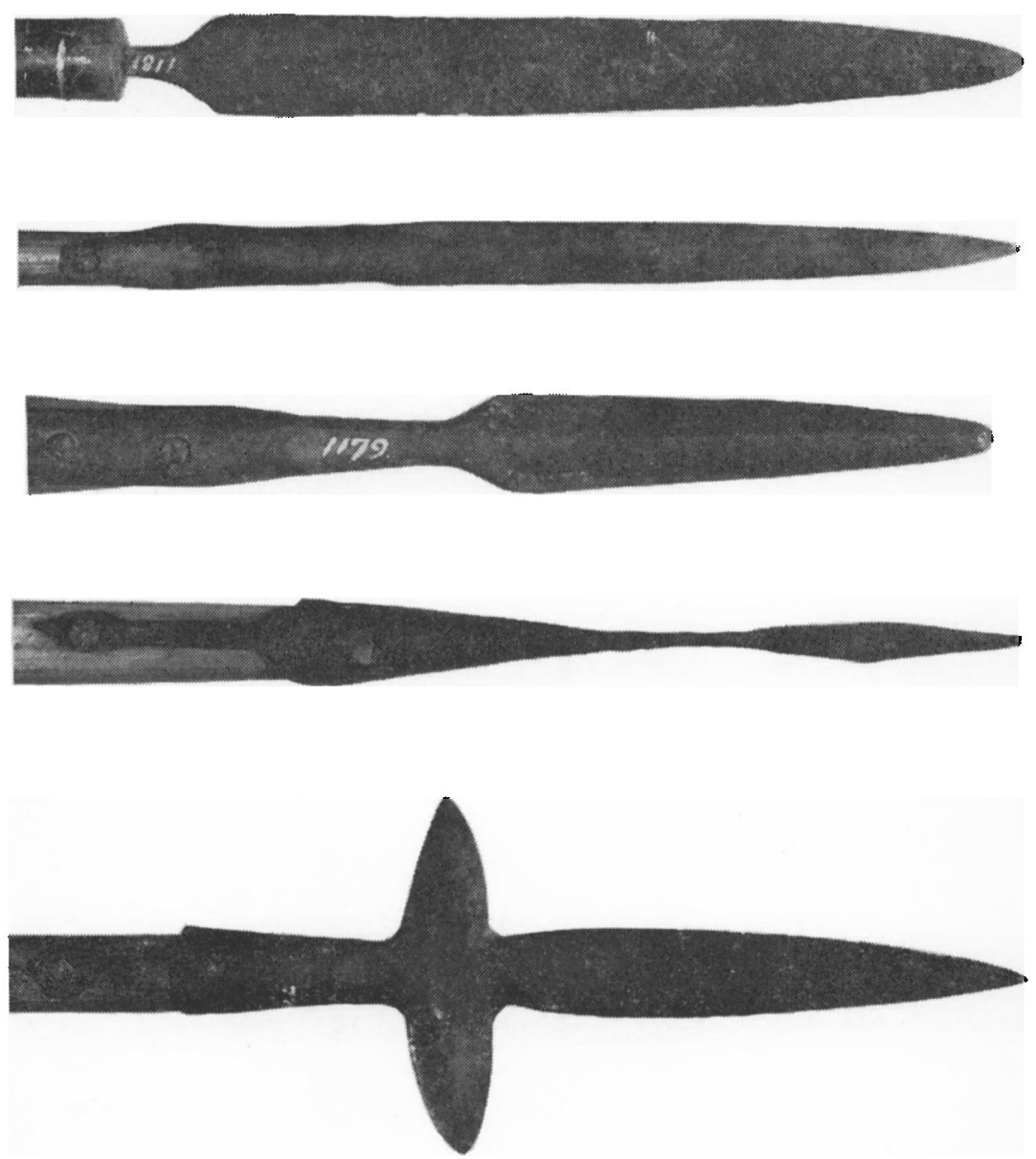

Fotograft af hjemmesmedede vdben pa Sønderborg slot

Kommandostaben bestod af:

Oberst H. C. Riegels, chef, krigsråd Riegels, kommandør for Als Nørherred og løjtnant Runacker, kommandør for Als Sønderherred. I hvert sogn var der en løjtnant, der havde ansvaret for sognets styrker, og han havde sine underbefalingsmænd, der mest bestod af folk, som havde gennemgået soldatertjenesten. F. eks. nævnes i Egen sogn:

Boelsmand Jørgen Blom, Sjellerup, løjtnant Chr. Klyhn, skolelærer P. Hansen, høker Jørgen Matzen, høker Wulf, Elstrup, pro- 
H. C. Riegels

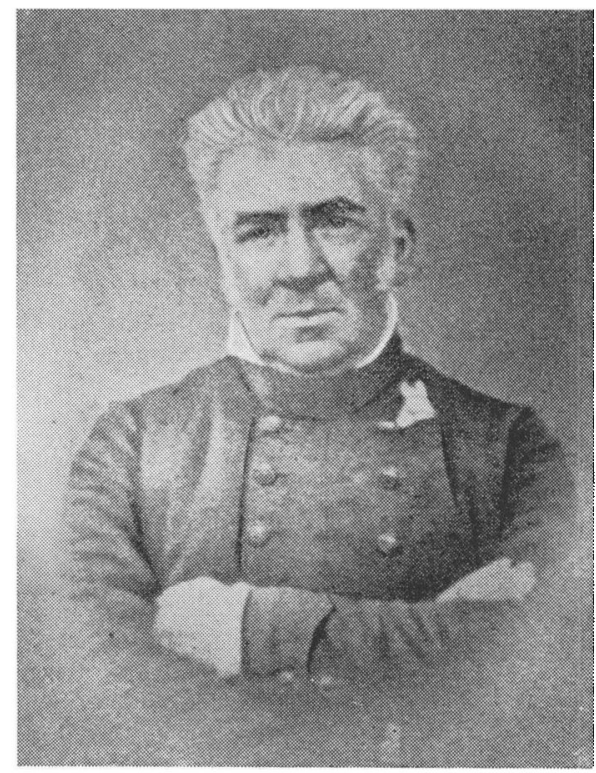

prietær Knudsen, Lysholm, og Hans Christensen, Katryd som underbefalingsmænd. Alarmplads var ved Egen kirke og eksercerplads i nærheden af kirken. I begyndelsen blev der øvet flittigt, senere hveranden søndag. Landbevæbningens hovedformål var at afpatruljere stranden, navnlig ved nat, men på udsatte steder Hardeshøj, Stolbromaj, møllebakken ved Guderup, Høgebjerg og Kegnæshøj var der vagt både dag og nat.

De danske krigsskibe, der krydsede omkring øen, havde bestemte signaler for at alarmere landbevæbningen. Når der blev affyret tre kanonskud og tre raketter, skulle man møde i Sønderborg. To skud og to raketter betød mødested Hardeshøj o. s. v.

Da også kirkeklokkerne skulle bruges i særlig påtrængende tilfælde, ved total alarm, blev det $\mathrm{i}$ den første tid forbudt at ringe med kirkeklokkerne om søndagen. I Hørup og Ketting kirker var der krudtlagre, og der måtte hverken ringes med klokkerne eller holdes gudstjenester. De fik senere en erstatning på 800 rdl.

Man forstår, at tiden ofte blev lang på de trættende nattevagter. Der fortælles fra Havnbjerg, at boelsmand Christen Hansen efter en alarm var rykket ud og gik på vagt ude ved Alssund ved 
Brandsbølskov. Han skulle afløses af Jens Jensen, men da denne ikke brød sig om at gå kystvagt om natten, tog Christen Hansen hans vagttørn for 4 skilling. Men ud på natten kom der en brusen ude på sundet ${ }_{\text {w }}$ så vi troede, at nu kom Prøjserne. Der kom nu ingen Prøjsere, thi det var en hjuldamper, der gik forbi. Det var en sjældenhed dengang. Vi var kun bevæbnede med lanser og spyd, men var prøjserne kommen, havde vi ganske bestemt gjort brug af demle

Ja, det var trættende og opslidende med de mange og lange vagter om natten, når det daglige arbejde skulle passes om dagen, og når tilmed søndagene gik med eksercits. En søndag mødte en boelsmand fra Havnbjerg, der skulle deltage $i$ en øvelse ved Egen kirke, med spadserestok og stillede sig blandt tilskuerne. Krigsråd Riegels, der ledede øvelsen, blev gjort opmærksom på manden og ville tale ham til rette. Manden svarede, at han nu havde været til ovelse hver søndag, men hans nabo havde været dispenseret. For mange år siden havde han lært eksercitsen bedre end her, nu ville han ikke være med til den komedie mere. Riegels lod ham spærre inde $i$ et hus i nærheden, og bagefter, da tjenesten var forbi, trak hans venner ham hen til Riegels. Man sagde bonden en undskyldning for, han mumlede den efter, og Riegels lod nåde gå for ret.

Når der i Almindelige Bestemmelser for Landbevæbningen på Als (se modst. side) er tale om mistænkelige personer (pkt. 14) så er det ikke uden grund. Vinteren 47-48 strejfede en mængde tyske håndværkssvende rundt på øen. Der berettes om, ${ }^{8}$ at de var blevet en sand landeplage, $\mathrm{g}$ at politiet ikke ville gribe ind overfor dette uvæsen. Hertugen var meget godgørende overfor dem og gav dem ovenikøbet $1 / 3$ rd. cour. i lommepenge. Deres ophold på øen var af hertugen beregnet på at have hvervede friskarer ved hånden'. Tilsyneladende forsvandt de alle ca. 8 dage før oprørets udbrud, og man påstod, at de gik i tjeneste i de slesvig-holstenske friskarer.

Den 6. april kom Frederik VII til Sønderborg og blev modtaget med jubel af en stor folkeskare. Stemningen på Als var nu udmærket, og de tysksindede lod sig hverken se eller høre.

Den 9. april inspicerede kongen landbevæbningen, først den nørherreds afdeling, i Hulekobbel ved Hjortspring, hvor der var samlet omkring $\mathbf{3 0 0 0}$ mennesker for at hylde ham. Den føromtalte herredsfoged dr. Steffens, der som bekendt var tysksindet, men 


\section{Plmindelige Beftemmelfer \\ for Ranbbevabbingen paa Mls.}

Sinfigten meb Eanbbetectringeh et:

1) $x_{1}$ besogte \$oen mob ficnbtigt Doerfalb.

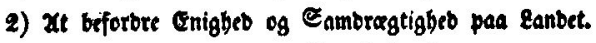

3) Xet optetbotide Drien ing Kgtelie- for Eopen.

4) $x_{t}$ fitter sen mob alli mistentelige gierfoner faafom epionet, Dw leberte ig bestige.

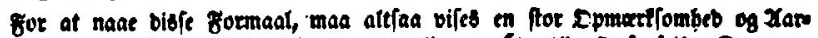
vaagenber paa goft og gatrouilic, on abrurlig og ofbentlig Epforfer! Dor maa vifes en beboarenbe Dpmattfomber paa alle faabanne Perfoner bet tunne fynes. mistantilige. De Fremmede paia Dorn maatte vel meeft oxre Ejenftant for en: faaban Epmortfombeb, bog maa benne itte gaac obre til pao eller forfolgelfe -

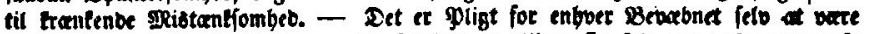
at Bronfer paa toolig Drben, og ligefaulioet at tillabe fig felo nogen Dovertsabelfe beraf fom fittiente at fie Xanose giore bit.

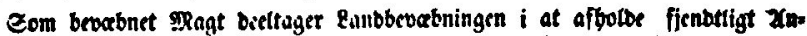
greb og Doerfalb. Eom Borgeriamfuno bibraget orn til at opretbolbe bet eggte jaotelanbife Einbelag, sijertigbeo til stongen og zabrelantet.

For at faa ben fornotne Xuriectie og Enyrle benborer under Eandbexabningen

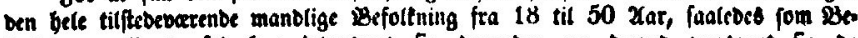
folthingen allerebe felv bat inboronet fig beruster, ing berbed paataget fis of Xjenftspligter fom berai flybe nemlig:

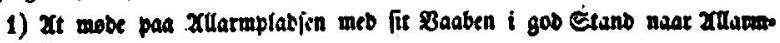
fignalet gioes.

2) Stle at ubeblive fia be befalcbe Basbenabelier uben gnibig Grunb, fou

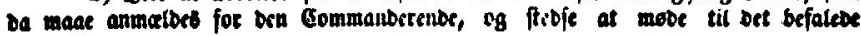
stotteflet.

3) Xetio at mebe $i$ orbentlig Wuallarming, boillen foruben ben boibe strabe, efterbaanben futbe loges at gjeres fan sgal fom muligt. Da en tort blaae fratte

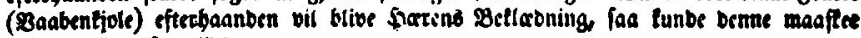
inbferes libs refer libt.

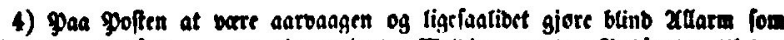

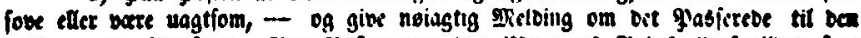

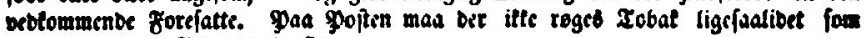
bre maa giores sib paa goften.

5) Bare indig og folgagtig mob be Commanberente, ba ellerd at Drben

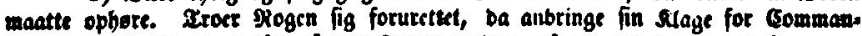
beuren alle Doetrabelier of gob Eiben melbes af be toende jerter Gomman beute til mig fom Ranbberabringens Cbef:

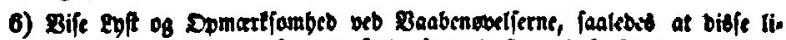
gefaameget lunne blive til Shyte for Det Sele, fom til forndielfe for ben Entelte.

7) Bare opmatefom paa Enburr, ber tan antaged for at oxre midtenter tig, for at opbage boab ulowligt en fig gerion mutigviis maatte fortage fig, og frar at anmelbe boab man bar bemartet. Dog bor man ogfaa bogte fig for at mobrebe Bingter og los enal, ber tum flabe og batte sRibtilit.

8) unber Baabenoberferac afbolde fig fra al xalen og omgaaed forfigtig weo fit Baben, faalebes at ban boetfen beftabiger fig felo eller ánoce ber itte exe giender.

9) Xlbrig glemme ben Xlvor og Befinbiglxb, ber anfianer en bevebnet SRanb, ifar naar bet gjalber zabtelandetb bellige Eag. unber fige zorbolb gjats ber bet ifar at folge Gommanbott meb Deligbro og Dpmartiombed.

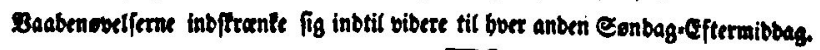

\section{Riegels,}

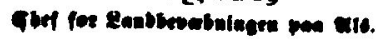

Affotograferet pd Sønderborg slot 
endnu sad i sit embede, var også til stede, men bønderne vendte ham ryggen og lod, som om de ikke så ham. ${ }^{10}$

Efter at kongen havde set på landbevæbningens eksercits, kørte han til Guderup præstegård, hvor han spiste frokost hos biskop Jørgen Hansen. Herfra kørte han til Majbølgård, hvor han inspicerede den sønderherreds afdeling, og efter vel endt inspektion kørte han til Sønderborg, eskorteret af 200 bønder til hest. De var bevæbnet med lanser, som de til ære for kongen havde pyntet med små dannebrogsflag. På vejen til Sønderborg blev kongens vogn flere gange standset af ordonnanser, der bragte ham meldinger fra slaget ved Bov. Efter kongens ankomst til Sønderborg kom et dampskib med fanger, dels regulære tropper, , dels alt muligt skrabsammen, nogle med, andre uden trøje, nogle med en sort, andre med en hvid hat o. s. v. . Den 10. april kom flere fanger, ca. 700 ialt. Kongen besøgte dem, før han rejste til Flensborg. De erklærede, at de mente at have kæmpet for kongen, og råbte hurra for ham! !

Kongen meddelte senere landbevæbningen gennem dens chef, at han var overordentligt godt tilfreds med den.

Efter slaget ved Slesvig, da insurgenterne var blevet forstærket af de preussiske hærafdelinger, og vor egen hær mátte trække sig tilbage, kom der igen hektiske og travle dage for den alsiske befolkning, og igen begyndte frygten for en slesvig-holstensk sejr at nage. Store troppemasser begyndte at strømme over til øen. Oberst Riegels havde i misforstået iver ladet den provisoriske flydebro fjerne, for at slesvig-holstenerne ikke kunne gå over sundet. $\mathrm{Nu}$ blev det grunden til, at vore egne tropper ikke så hurtigt som ønskeligt kunne trække sig tilbage. Stort mandskab blev fra Als sendt over for at forrette skansearbejde på Dybbølbjerg - ofte 100 mand fra et sogn. - Den 25. april blev der, samtidig med ordren til skansearbejde, slået alarm, og landbevæbningens folk måtte hurtigt hente deres våben og stille ved Hørup kirke. Alt dette skabte stor forvirring - og ingen vidste noget sikkert. Heldigvis fik man dog alle de tropper, der stod på Sundeved, over inden aften. De var trætte og udmattede, men i stedet for at lade de først ankomne få de længst bortliggende kvarterer, måtte de sidst ankomne marchere den lange vej til Nørherred. Mange tog nødkvarter $i$ den første lade, der var plads $i$, hvorefter de fortsatte dagen efter til deres kvarter. 
Herefter var Als retraitestilling for en stor del af den danske hær, og indkvarteringerne tyngede hårdt på beboerne - ofte var der 20 mand på en gård. Der nævnes endda en indkvartering på 8000 mand alene i Ulkebøl sogn. Dertil kom de mange ægtkørsler. $I$ årene 1848-49 blev der i det augustenborgske distrikt forrettet 22.209 kørsler. Ofte var et køretøj borte i $5-6$ dage.

Efterhånden blev det sådan, at sognene i fællesskab havde lejede køretøjer til dette formål. Arbejdet hjemme skulle jo også passes. Mange af de indkvarterede soldater tog gerne en hånd med, når der var travlt, og der rådede $\mathrm{i}$ det hele taget et udmærket forhold mellem militæret og befolkningen.

Alt imens fortsatte landbevæbningen med ovelserne. Chefen, oberst Riegels, inspicerede ofte disse øvelser. *Han lod i forvejen sin ankomst højtideligt melde, holdt formanende taler, gav gode râd og skønne lofter - som han ikke kunne holde. - Til sidst fik han en slags adjudant i Carl Drescher, som havde solgt sin gård i Jylland og nu gik ledig i Nørborg. Han blev kaldt leutnant og fik en slags uniform med epauletter, forskellig fra de virkelige officerers.$^{12}$

Desværre var det kun så som så med den frivillige tilslutning til landbevæbningen. Folk med tyske sympatier blev simpelthen "tvunget til at gå frivilligt med «, og selv flere af hertugens stab, deriblandt hans forst- og jagtbetjente blev indrulleret og måtte deltage $i$ øvelserne. I den anledning må løjtnant Runacker indgive en beretning til oberst Riegels om disses sindelag og opførsel. Um overførster König skriver Runacker, at han whar søgt at gøre ovelserne latterlige og tillige søgt at indjage folk skræk for, at hertugen nok skal vende tilbage, så hvis de har deres kone og børn kær, var det klogere at blive hjemme, end at gå og eksercere med et så dårligt våben som et spyd " ${ }^{13}$ Sådan får alle de hertugelige forst- og jagtbetjente deres skudsmål, og med en enkelt undtagelse viser de sig at være højst antidanske og modvillige mod at deltage $i$ øvelserne.

En skrivelse fra oberst Riegels til overførster König lyder heller ikke særligt *frivillig «:

An den Oberförster König!

Der Holzvagt Andresen hat sich unverzüglich bei mir einzustellen betreffend warum noch nicht an die Waffenübungen 
und den Dienst der hiesigen Volksbewaffung Theil genommen hat.

Die Commandantschaft auf Alsen 3. Maj 1848.

Riegels.

Dagen efter demonstrationen ved Augustenborg slot, hvor også våbenlageret blev beslaglagt, udgik der fra hofråd Barth en skrivelse til alle hertugens jagtbetjente om, at de inden et bestemt klokkeslet skulle aflevere deres våben. I en indberetning fra oberst Riegels meddeler han, at "når de $i$ landbevæbningen har vist sig pålidelige igen, skal de atter bevæbnes med egne eller kongelige geværer ${ }^{24}{ }^{24}$ Jagten bliver gennem alle krigsår et meget omt punkt. De første dage efter oprørets udbrud gik alle på jagt. Hertugens rigelige vildt havde altid gjort stor skade på bøndernes korn - nu så de en lejlighed til at få det udtyndet. König ville have dem straffet, men Riegels gik i forbøn for dem og vil have dem til at forstå, at det er bedst, der er orden. "Med få undtagelser kan den alsinger bonde med det gode bringes til alt godt, og han har megen agtelse for lovlighed og anstændighed $\ll{ }^{15}$ Folkerådet andrager til civilgouvernøren: "Vi tillader os tillige at bede om, at det udtrykkelig må vorde udtalt for de hidtil værende forstmænd, jagtbetjente og revierjægere, at de ville blive betragtet som krybskytter, når de med bøsse træffes på fremmed mands mark, og afstraffede efter lovens bud " ${ }^{16}$

Bøtten er vendt om - nu er det bønderne, der vil have jagtbetjentene straffet - før var det omvendt. Nogen stor styrkelse af landbevæbningen, hverken i slagkraft eller ånd, har disse tvungent indlemmede næppe været.

Det, der gjorde Riegels populær i hans første "regeringsdage", var ellers netop det, at han sørgede for, at de mest upålidelige embedsmænd blev fjernet fra deres stillinger. Allerede 10. april suspenderedes herredsfoged Steffens, hof råd Prehn og borgmester Langreuter. Hofråd Barth havde allerede den gang forladt Als. Hofpræsten Germar blev også afsat, ligeledes pastor Schlajkjer i Asserballe og pastor Petersen i Notmark, der var ivrige tilhængere af hertugen. To andre præster var også i søgelyset, pastor Ahlmann i Svenstrup og pastor Hoeck i Ketting. Sidstnrevnte havde »efter sædvane nævnt stedets fyrste i kirkebønnen, men så stod næsten hele menigheden op og forlod under megen støj kirken ". ${ }^{17}$ 
Pastor Petersen i Notmark var dumdristig nok til at vende tilbage, efter at våbenstilstanden var indtrådt, men hans ophold $i$ Notmark varede ikke længe, for en skønme dag indfandt der sig en afdeling af landbevæbningens kavalleri, ca. 30-40 mand, anfort af møller Andersen pá Mommark hedemolle (dannebrogsmand). De besatte alle indgange til præstegård og kirke og sendte bud til sognets byer, at nu skulle de med til at bortføre præsten, hvis de ikke ville anses for tyskere. Afdelingen, for største delen i uniform, red ind pâ marken og sendte 3 mand, skolelærer Hansen fra Asserballeskov, boelsmand Bladt fra Mommark og boelsmand Nielsen fra Jestrup, ind til præsten.

De erklærede over for ham, at de ikke ville tale ham på øen nu, da han var suspenderet. Hans æresord for, at han ville være borte inden 24 timer, ville de ikke tage imod, »ti de troede ikke en lysker«. Han lovede at være færdig inden to timer, men allerede efter $1^{1 / 2}$ times forløb var han til disposition. Så red de bort med ham, tre mand høj, præsten også til hest, i midten foran. Det gik i skarpt trav det meste af vejen til Sønderborg til færgen. Færgen var imidlertid lige gået, og da folk stimlede sammen, tilbød anføreren ham en båd, for at undgå »infelter " (forviklinger). Præsten gik ombord på den, og hesten måtte svømme bagefter. Da afdelingen så ham vel $\mathrm{i}$ land på den anden side sundet, vendte de om, ved rådhuset gav de kong Frederik VII et hurra, hvorefter de skiltes. Iøvrigt var det hele gâet for sig med påfaldende militær orden og iagttagelse af alle mulige høflighedsformer, så at endog den bortførte præst gav anføreren hånden til afsked og takkede ham for beskyttelse. ${ }^{18}$ En anden beretning slutter med ordene: Hvorved alting gik roligt og ordentligt til, (H. C. Bladt).

At Riegels vidste besked med denne bortførelse, er der vist ingen tvivl om. Der påstås, at der hos landbevæbningen ${ }^{19}$ lå en liste over personer, hvem den samme skæbne var tiltankt. Men Riegels havde overskredet sin kompetence. Han var allerede 24. maj 1848 bleven suspenderet som kommandant. Han havde lagt sig ud med militæret, som ikke havde meget tilovers for hans dygtighed og indsigt. Den 17. var han rejst til København, efter at han ved en vâbenøvelse ved Lysabild kirke havde formået at fá et par bonder, H. C. Bladt og Hans Nielsen, Jestrup, til at ledsage sig. Han ville retfærdiggøre sig angående nogle af sine handlinger - bl. a. fjernelsen af pontonbroen, og han ville gøre forslag til nye foran- 
staltninger pá øen (Folkerâdet. De fik ikke kongen i tale, men talte med nogle ministre. Dagen efter hjemkomsten bliver han så afsat som kommandant for Als, men udnævnt til civilguvernør for Als og Erø, og som et plaster på såret avancerer han til oberst i arméen. Han er stadigvæk chef for landbevæbningen.

Efter bortførelsen af den Notmark præst får landbevæbningen $i$ en skrivelse til dens chef (Riegels) en skarp irettesættelse af general Hansen, der nu er kommandant i Sønderborg, fordi en så stor bevæbnet skare er trængt ind i Sønderborg uden hans tilladelse. Da general Hansen kort efter forlader Sønderborg for at blive krigsminister, tilkalder hans efterfølger, general Bülow, hovedmændene og giver dem en speciel irettesættelse, men var dog meget venlig overfor dem. ${ }^{20}$

I en skrivelse fra kancelliet til Riegels erindrer man ham om hans beføjelser. Det hedder heri ordret: „Was ferner lhre Funktion als Chef der Landbewaffung betrifft, so wird Ihre Wirksamkeit hierfür ausschlieslich militärische Zwecke, die zum Schutz und zur Sicherheit der Insel gerechen, zu verfolgen haben, und werden Sie sich an dieser Beziehung gefällig mit der höchsten Militärbehörde auf der Insel in Verbindung setzen, wohingegen jede art der Ausübung einer polizeilichen Aufsicht seitens der Volksbewaffung nur dann wird eintreten können, wenn zu dem Behufe die Assistenz jener Bewaffung von dem Oberbeamter oder dem betreffendem Polizeibehörde auf der Insel in Ausspruch genommen wird « ${ }^{21}$

Altså ikke foretage sig noget pâ egen hând med landbevæbninger, men pænt sætte sig i forbindelse med hæren først, og i politimæssig henseende vente, til den bliver tilkaldt af politimyndighederne.

I et brev fra kancelliet til konstitueret overinspektør for Als, Hornemann, beder man ham om, at han »i de Augustenborgske bønders interesse vil våge over, at guvernøren (Riegels) ikke pålægger dem flere byrder, end han er berettiget til " ${ }^{2 *}$

Nu er det imidlertid sjældent bønderne, der klager over oberst Riegels, han gor alt for at komme til at stâ på en god fod med dem, og indenfor landbevæbningen er hans popularitet usvækket, til trods for, at eksercitsen ofte synes tidsspildende og besværlig. og kystvagterne lange og ensformige. Flere gange er landbevæb- 
ningen alarmeret - den 21. april til Lysabild kirke, den 25 . april ved Hørup. Da der blev kæmpet på Sundeved den 5. juni, stod de i beredskab hele natten, og de, der havde geværer, fik udleveret skarpe patroner. Ofte hørtes der skydning og kanontorden fra Sundeved - ofte gik rygterne, at nu var der landgang her eller der - der blev slået alarm, og landbevæbningen rykkede ud i storre eller mindre afdelinger.

Tjenesten er nu lagt i faste rammer, og de almindelige bestemmelser er bleven efterfulgt af en chefshefaling udsendt til alle sognechefer. Den følger her: $:^{23}$

\section{Organisation og tjenestereglement for landbevæbningen på øen Als}

\section{Landbevcebningens styrke.}

Landhevæbningen er inddelt $i$ to afdelinger (korps), en for Sønderherredet og en for Nørreherredet, hvis styrke består af det tjenstdygtige mandskab, der er fyldt det 18de, men endnu ikke har fyldt det 50de år, og som ikke er $i$ aktiv tjeneste $i$ arméen.

Styrken består for tiden:

I Sanderherredets 8 sogne af 1546 mand.

I Norreherredets 5 sogne af 1257 mand.

\section{Landbevabningens inddeling.}

1. Hvert sogns mandskab danner et kompagni, der består af alle spydbevæbnede og alle geværbevæbnede, samt af de af hvert sogn afgivne kavallerister eller ridende ordonnanser, der er hevæbnede med lanser eller sabler.

2. Ved våbenøvelserne, der foretages kompagnivis, er disse inddelte afdelinger på 24 mand eller peletons på 12 roder, og disse igen $i$ underafdelinger på 12 mand, eller sexioner på 6 roder. Ved større våbenøvelser, der foretages af flere kompagnier (sogne) dannes der af disse særskilte med gevær og spyd bevæbnede batailloner, hvoraf de sidste er at betragte som reservebatailloner med tilhørende reserve- eller spydbatailloner, nemlig:

I Sønderherredet 2 geværbevæbnede batailloner med tilhørende reserve eller spydbatailloner. 1. bataillon dannet af sognekompagnierne i Lysabild, Hørup og Ulkebøl sogn med en fælles exerserplads på Majbølgårds kobbel. 
1. bataillon dannet af sognekompagnierne fra Tandslet, Notmark, Asserballe og Ketting sogn med en fælles exerserplads på Gammelgårds kobbel. Sognekompagniet på Kegnæs deltager kun ved enkelte lejligheder i 1 . bataillons våbenøvelser og øver sig iøvrigt på selve Kegnæs.

I Nørherred ligeledes 2 geværbevæbnede batailloner med tilhørende reserve- eller spydbatailloner. 1 . bataillon dannet af sognekompagnierne i Nørborg, Oksbøl og Havnbjerg sogne med fælles exerserplads på Hjortsprings kobbel.

\section{Landbevobningens befalingsmaend}

Kavalleriet forener sig enten i en eskadron i Sønderherredet og en i Nørreherredet, eller også i de halve eskadronarder, der hører til de anførte batailloner. Hvert kompagni kommanderes af en kommanderende befalingsmand, og afdelinger, peleton og sexion af underbefalingsmænd.

Jægerne ved hvert kompagni har en kommanderende befalingsmand for sig, hvilket også er tilfældet med de spydbevæbnede og samtlige kavallerister ved hvert kompagni.

Såvel ved kompagnierne med tilhørende jægere som ved de såkaldte ordonnanser er en af befalingsmændene ansat som næstkommanderende, der, når den kommanderende befalingsmand er fraværende, overtager kommandoen over kompagniet eller de samlede ordonnanser, lige som disse overalt forretter tjeneste lig en major ved de regulære batailloner, og påligger det dem endvidere at have tilsyn med våben og ammunition.

Foruden de anførte befalingsmænd under gevær, har hvert sogn eller kompagni en sognechef, der, uden hensyn til om han tillige er kommanderende befalingsmand under gevær, står i spidsen for hele landbevæbningen i sognet, og således modtager og udfører alle, såvel mundtlige som skriftlige ordrer, der fra chefen eller kommandøren måtte udgå udenfor de egentlige våbenøvelser.

Endvidere påligger ham:

a. - I overensstemmelse med $\S 5$ af »de almindelige bestemmelser for landbevæbningen på Als * til vedkommendes kommandør at indmelde de forseelser, der begås af landbevæebningens mandskab $\mathrm{i}$ chefens eller kommandørens fraværelse, og som såvel af ham, som af den kommanderende og næstkommanderende 
hefalingsmand måtte befindes at egne sig til en større irettesættelse, end de selv måtte foranledige til at uddele.

Disse skulle også i forening gøre forslag til kommandøren over dem af bevæbningens mandskab, der for svageligheds- eller andre grunde bør gå ud af styrken, ligesom det formentlig er dem, der bør våge over vedligeholdelsen af den gode ånd $\mathrm{i}$ bevæbningen, at føre regnskab over de forekommende udgifter og besørge sammes reparation og udbetaling, og derefter årligt til nytår at indsende det forløbne års opgjorte regning til den vedkommende kommandør.

At føre styrkelisten over sognets mandskab ved landbevæbningen og ved udgangen af hvert års marts måned $\mathrm{i}$ nærværelse af samtlige befalingsmænd at foretage en revision af samme og derefter at indsende af- og tilgangslisterne til kommandøren, der derefter foranstalter det fornødne angående det tiltræedende og fratrædende mandskab.

Stedse at være nærværende ved våbenøvelse, hvorved han medbringer mandtalslister, for derefter at opråbe mandskabet, samt fortegnelse over dem, der enten af sygdom eller andre, af ham anerkendte gyldige grunde udebliver, eller er bleven fritaget for at møde. Dersom han ikke tillige er kommanderende befalingsmand, er han personlig fritaget for at deltage $i$ våbenøvelserne, men behøver, som ovenanført, kun at give møde ved samme, ligeledes er han fritaget for at deltage i nogensomhelst vagtt.jeneste.

Besørge samflige tilsigelser, hvorved han dog assisteres af en befalingsmand $\mathbf{i}$ hver by, der efter modtaget ordre bekendtgør denne for hver enkelt af byens mandskab.

Han våger over, at alt til alarmsignalerne henhørende er i god orden, ligesom den derværende post står under hans specielle tilsyn.

\section{Landbevcebningens pligter.}

Til de pligter, der er anførte i "de almindelige bestemmelser for landbevæbningen på Als" tilføjes: At der af de ridende ordonnanser i tilfælde af alarm møder en af hvert sogn hos landbevæbningens chef, ligesom de efter givne befaling af kommandøren eller overbefalingsmændene er pligtige til at patruljere eller afgive anden ordonnanstjeneste, hvor og når samme behøves, hvorimod de 
er fritagne for al vagttjeneste. Ligeledes møder enhver søndag morgen kl. 7 hos den højstkommanderende $i$ herredet, altså for Sønderherredet i Sønderborg _ - de skulle også ved sognechefens foranstaltning, når alarm påkommer om natten, bidrage til med hurtighed at vække og sammenkalde landbevæbningens mandskab. De må $i$ enhver tjenesteforretning vise at være værdige til den tillid, der er dem skænket.

Sønderborg, den 19. august 1848.

Riegels.

Efter våbenstilstanden den 26. august 1848 kom kongen igen til Als. Den 10. sept. var en del af øens beboere til taffel hos ham. og i dagene efter holdt han audiens for civile og militære myndigheder. Ved en samtale med folkerådet udtalte han, at han ikke kunne tænke derpå uden at få tårer $\mathrm{i}$ øjnene. Da man spurgte ham, om der var udsigt til, at hertugen ville komme tilbage hertil, svarede kongen: "Aldrig, og skulle han snige sig ind alligevel, sá erklærer jeg ham herved for "vogelfrei «

Den 13. september inspicerede kongen krigsmagten, både militæret og landbevæbningen i Rumohrsgårds kobbel.

Den 14. sept. udstedte han følgende dagsbefaling:

Da Vi ved den i Gaar stedfundne Presentation for Os af Alsinger Landbevæbning havde Lejlighed til at bemærke den glædelige Fremgang, som denne Væbning siden sammes Præsentation for Os $\mathrm{i}$ afvigte April Maaned har haft, ligesom Vi ogsaa af de, angaaende bemeldte Væobning modtagne Beretninger har erfaret den gode Aand, som besjeler samme, og den gode Tjeneste den har præsteret under de Farer, der truer Landet, saa finder Vi Os foranlediget til herved at tilkjendegive Vor Allernaadigste Tilfredshed og Tak for deres i saa Henseende udviste Virksomhed, idet Vi derfor paa nærmere Indberetning om Væhningens fuldstændige Uniformering ville tage i Allernaadigste Overvejelse, hvorvidt den ridende Afdeling maatte være at tildele en Standard, og Fodafdelinger en Fane, samt Førerne passende Distinktioner. Hvilket vi saaledes Allernaadigst give tilkjende til almindeligst Efterretning og videre Bekjendfgørelse for hele Væbningen.

Sonderborg, den 14. September 1848.

Frederik $R$. 
Hertil føjer Riegels:

»Idet jeg meddeler den hæderlige landbevæbning denne Hans Majestæt Kongens allerhøjeste tilfredshed med bevæbningen, der må være den en hellig opmuntring til fremdeles at bevare Hans Majestæts Kongens og hele landets påskønnelse, er det tillige en kær pligt for mig at meddele såvel de herrer overbefalende krigsråd Riegels og kaptajn Runacker, som de underbefalende og mandskabet, enhver især, min tak for den gode ånd, der ved enhver lejlighed udtaler sig $\mathrm{i}$ bevæbningen, og som også viste sig ved presentationen for Hans Majestæt Kongen.

\section{Brave landsmænd!}

Holder sammen og være enige $\mathbf{i}$ det gode, så I vil bevare alsingerne et hæderligt minde nu og i eftertiden, og eders efterkommere vil mindes jer med taknemlig berømmelse for eders troskab mod konge og fædreland og for eders enighed og samdrægtighed.

Med våbenøvelser og vagttjenester har det sit forblivende ved den tidligere hestemmelse, at de ophører, hvorimod der som hidindtil hver søndag mader en ridende ordonnans for hvert sogn i Sønderherredet.

Sønderborg, den 15. september 1848.

Riegels.

Til den gode tjeneste kongen taler om, hører, foruden kystberogtningen, også udsendelsen af ridende patruljer på Sundeved - der tales om en forpostkæde tværs over halvøen, og så længe, der var tale om en frivillig ordning under landbevæbningen, har der muligvis også været Sundevedboer med i denne forposttjeneste. Senere er den naturligvis overtaget af ordinære tropper.

Der er flere steder tale om landbevæbningens uniformering, der skulle bestå af blå frakke med hvid krave og skulderstropper med bogstav A. L. B. Desværre findes der slet ingen af disse gamle uniformer. Man har måske hjulpet sig ved at sy en hvid krave på de blå vadmelsfrakker, der den gang horte til bondens daglige påklædning, måske også syet et par blanke knapper i. Landbevæbningens fulde uniformering er vist aldrig blevet gennemført, og efter krigen har man nok fjernet den hvide krave og knapperne og omvendt frakken til daglig brug. 
Jeg har flere gange navnt folkerâdet, og det er heller ikke nemt at fortælle om landbevæbningen uden at strejfe folkerådet - fordi begge er udsprunget af samme kongetro og fædrelandskærlige ånd - og har samme ledellse.

Som før nævnt havde oberst Riegels ved en forsamling af landbevæbningen ved Lysabild kirke bedt to mand om at ledsage sig til Kobenhavn for at tale med kongen og ministrene. Det var ham sikkert en stor skuffelse, at han ikke fik kongen i tale - - de var gode bekendte, måske ogsâ venner, fra den tid kongen, som prins, havde opholdt sig i Fredericia. Hovedformålet for Riegels, Bladts og Nielsens rejse til Kobenhavn synes at have varet at opná en tilladelse til at oprette en repræsentativ forsamling, et folkerâd, til at drøfte øens anliggender, evt. være râdgivende overfor regeringen. Efter hjemkomslen samler Riegels så igen landbevæbningen samme sted, den 4 . juni, for at meddele den resultatet af rejsen til København. Den 9. juni er en valgkommission, udnæunt af regeringen, bestående af kammerherre, oberst Riegels, biskop J. Hansen og H. C. Bladt samlede i Guderup præstegârd. Den har ret til at supplere sig med 2 mand, borgerkaptajn (stadshauptmand) Hanssen (Norsk) fra Sonderborg og husfoged, krigsråd Riegels fra Norborg. Regeringen havde bestemt, at valgloven til stænderforsamlingen skulle være bestemmende for valgretten, medens valgbarheden skulle være uindskrænket.

Den 21. juni er valgkommissionen igen samlet i Guderup og vedtager, at valg til folkeråd skal finde sted den 3. juli i Gammelgårds kro, den 4. juli på Sønderborg rådstue og den 5 , juli i Nørborg amtsstue. Den 2. juli er der provevalg i Ketting kro, og her er der megen interesse for sagen. Ved valgene de følgende $\mathbf{3}$ dage blev følgende valgı: biskop Jørgen Hansen, kobmand Günthersohn, stadshauptmand Hanssen (Norsk), krigsråd Riegels, købmand Matzen fra Guderup, Hans Christensen fra Egen, Christen Bonefeld fra Ulkebøl, boelsmand Kaad fra Tandslet og stænderdeputeret H. C. Bladt fra Tandsgård.

Den 1. august 1848 åbnedes folkerådet i Ketting bispegård. På det første møde drøftes en forligskommission for øen, og der formes en prolest mod de slesvig-holstenske overgreb. Denne protest bliver sat $i$ omløb på øen til underskrift og tænkes sendt til den tyske centralregering i Frankfurt og til general Wranzel. Den har nok ikke hjulpet meget. I begyndelsen er det mest aens anlig- 
gender, der droftes, navnlig hoveriets afskaffelse i det augustenborgske distrikt, hvor det foles forfærdeligt ydmygende at gore hoveriarbejde for en mand som hertugen.

Da våbenstilstanden træder i kraft, kommer lidenskaberne i kog. Det var jo meningen, at den såkaldte fællesregering skulle styre hele hertugdømmet, også Als og Erø, og rygterne gik, at den ville blive afløst af en slesvig-holstensk regering. At fællesregeringen $i$ forvejen var mere tysk- end dansksindet, var man allerede den gang klar over. Og alsingerne protesterer. De vil beholde deres eget styre, deres egen immediatregering, vil ikke overlades til fællesregeringens forgodtbefindende. De har varet kongen tro, og Als har aldrig varet erobret af fjenden, de vil ikke opgive håbet om, at de må blive så nær knyttet til Danmark som muligt.

I de dage tænker en del af de mest fremtrædende dansksindede alsingere på, om de måske bliver nadt til at flygte bort fra "deres hjem og deres kære".

Der spores da også en særlig aktivitet i landbevæbningen efterâr 1848, der giver sig udtryk $i$ en del chefsbefalinger. Efter mønstringen 13. september falder der en mindre ordensbyge.

I chefsbefaling fra 17. september hedder det:

1. Hans Majestæt Kongen har, for at hædre landhevæbningen, benâdet følgende to befalingsmænd af kavalleriet og følgende to af infanteriet med dannebrogsmandenes hæderstegn:

sognechef Hans Christian Andresen pá Hedemglle og sognechef Chresten Klyhn i Guderup,

skolelærer Hansen i Dyndeved,

skolelerer J. Iversen i Ulkeholle.

Disse fire mænd bærer således det udvendige tegn på den hader, hvortil H. M. Kongen har erkendt landbevæbningen at have gjort sig fortjent til H. M. tilfredshed.

2. Da jeg forrejser i 4 dage, så overdrager jeg i denne tid herred kommandoen til krigsråd Riegels.

3. Nâr tyske vagabonder opfører sig slet, eller endog overfalde folk med grovheder i deres egne huse, da skal vore ordonnanser arrestere sådanne personer og assistere synsmendene ved deres arrestering til herredsfogdiet.

Efter ordre:

$$
\text { C. Drescher, adjutant. }
$$


Chefsbefaling af 24. sept. 1848.

1. Landbevæbningens chef igen returneret og har overtaget kommandoen.

2. Den til i dag kl. 3 eftermiddag berammede ovelse for kavalleriet ved Augustenborg udsættes til næste søndag eftermiddag til samme tid, da chefen har flere ting at aftale med mandskabet.

3. Alle vagabonder, som tiggende fjerner sig fra landevejen, anbefales til landbevæbningens særlige opmærksomhed. De bliver at pågribe og straks at transportere til vedkommende herredsfoged.

4. Så længe det endnu står $i$ det uvisse med våbenstilstandens anerkendelse møder ordonnanserne hver søndag morgen som sædvanlig.

Sønderborg, den 24. sept. 1848.

\section{Riegels.}

Chefsbefaling den 1 . oktober.

1. Den til i eftermiddag berammede kavalleri-eksercits udsættes indtil videre, ligesom dette også er tilfældet med våbenøvelserne $\mathrm{i}$ almindelighed.

2. Omhyggelighed med geværerne og disses rengorelse anbefales til alle kongelige geværer.

3. For at befordre den af $H$. M. Kongen givne opmuntring til, at landbevæbningen efterhånden vil uniformere sig, bekendtgøres herved, at alt det unge mandskab, når det udskrives og møder til tjeneste, erholder betaling for deres blå uniformfrakker, benklæder og huer.

Riegels.

Chefsbefaling den 8 . oktober 1848 .

1. At jeg til H. M. Kongens fødselsdag den 6. okt. som øens civilguvernør har bevidnet $H$. M. K. hans tro alsingers lykønskninger bringes herved til landbevæbningens kendskab.

2. Med hensyn til, at våbenstilstandsbetingelserne endnu ikke overalt er trådt i fuld kraft, indskærpes den i de »Almindelige Bestemmelser for Landbevæbningen , $§ 7$ anbefalede opmærksomhed - dog skal iflg. skrivelse af 4 . ds. anmeldelse ske til vedkommende politiøvrighed, under hvis område nærmere undersøgelse er henlagt.

Sønderborg civil-guvernement 8. 10. 1848. 
Folkerådet samledes den 9. okt. og beder regeringen i København om at måtte beholde deres egen immediatregering. Denne bestod af grev Carl Moltke, som oprindelig var udset til at være præsident for fællesregeringen, men forhindret deri af de ham fjendtligt sindede slesvig-holstenere, og derfor måtte nøjes med den mere beskedne stilling som præsident for immediatregeringen for Als og Erø, hvorfra han dog kort efter trak sig tilbage, să denne derefter kun bestod af amtmand Johannsen og biskop Hansen. Der holdes i de nærmeste uger ofte møder i folkerådet, og emnet er regeringens svage holdning og de utilstrækkeligt afklarede forhold med hensyn til Als og Ærø; der tales ogsã om en udvidelse af folkerådet og holdes et møde derom i Svenstrup. I et møde den 30 . okt. besluttes det at sende en deputation til Kobenhavn » for at bede om, at civilguvernør Riegels mâtte blive tilforordnet immediatregeringen. Jeg modsatte mig dette forslag, ligeledes husfoged Riegels fra Nørborg. - Vi ville afvente begivenhedernes gang. - Derover blev kammerherre Riegels hensat $i$ en uhyre alteration og erklærede, at han ikke kunne fungere som civilguvernør, hvis han ikke fik en mere udstrakt myndighed. ${ }^{24}$ * Altså måtte en deputation afsted. (Bonfeld og P. Møller, 2 borgerrepræsentanter for Sønderborg by og 1 sekretær). Deputationen fik det løfte, at Als og Erø ikke ville blive overdraget til fallesregeringen, inden det var bevist, at den overholdt våbenstilstandsbetingelserne og, man fik sikkerhed for, at de love, den ville indføre, ikke stred mod danske interesser. Med h. t. kammerherre Riegels ville man afvente kongens afgørelse. Og Riegels mâ åbenbart have haft en god ven i kong Frederik VII, for denne onskede, at Riegels selv skulle overtage immediatregeringens forretninger, og at Johannsen og Hansen kunne afskediges med tak for, hvad de hidtil havde udrettet. Dette passede imidlertid ikke Knuth, og han lod Johannsen og Hansen sidde og supplerede med Riegels.

Ind imellem skete der det, at hertugen af Augustenborg omkring 1. november kom til Graasten, og at en del af hertugens venner fra Als var taget derover for at hilse på ham. Dette vakte en uhyre harme i befolkningen, "man" sendte bud rundt på øen for at få folk til at møde i Sønderborg for at hindre dem i at komme tilbage. Der mødte omkring 2000 mand. Hos brofogden fik man en fane, nogle musikere havde man også med, og med fane og musik $i$ spidsen marcherede man til general Hansens 
kvarter. Man sendte en deputation op til ham, som tolkede befolkningens vnske om, at færgen mátte blive stoppet for de hjemvendende tyskere. Folkeskaren råbte hurra for ham og drog sá videre til borgmesteren, immediatregeringen og til civilguvernor Riegels. Men myndighederne var ikke tilbøjelige til at imødekomme den ophidsede folkeskares onsker. De bad deputationen om at udforme sine onsker skriftligt og ville sa gøre, hvad der var ret og billigt. Det er ud fra denne tildragelse, at episoden med præsten i Notmark mâ ses. Et par andre eksempler på selvtægl skete der ogsã, men her var det dog ikke landbevæbningen som sádan, der var impliceret - det havde general Hansen jo taget stærkt afstand fra - nej, det var bare sbønderne «. Den 10. november drog alle bønder fra Verthemines lehn hen til gården for at lage forpagterindens son til fange - han tjente som frivillig i insurgentarmeen, og de mente, at han var laget hjem under våbenstilstanden; endvidere erklærede de, at de intet hoveriarbejde ville udføre, sâ længe han sad på gården. Sønnen var imidlertid ikke hjemme, ihvertfald fandt de ham ikke, så de måtte tage hjem med uforrettet sag.

Hos skolelærer Bargmann i Lebøl havde man heller ikke rigtig held med sig. Bargmann havde også været med i Graasten og var i den anledning blevet idømt en bøde på $7 \mathrm{rdl}$. for at have forsømt skolen. Dem betalte han ikke, og han processer om denne bøde. Kort forinden havde man afhentet protokollen over "Brandforsikringen for mobler og effekter", som han var formand for. Han er en af de allerivrigste slesvig-holstenere og har endnu hertugens og hertugindens billeder hængende på væggen. En aften kommer der så 3 bevæbnede mænd ind til ham, men træffer ham ikke hjemme. Konen vil undvige, men bliver holdt op. Så tager de hertugbillederne ned fra væggen, bærer dem udenfor og med geværet bliver hertugparret henrettet $»$ in elfigie .

Der kan vist ikke herske tvivl om, at Riegels er vidende om disse aktioner, og da hans varme danske hjerte og iver i tjenesten ofte forer ham i modsætningsforhold til de mere formfuldendle herrer af immediatregeringen, Johannsen og biskop Hansen, er disse ikke tilbojelige til at optage ham som medlem. Han soger orlov og rejser hjem til Snoghøj. Og så stâr bâde landbevæbningen og folkerådet uden hoved -- og alsingerne er vrede - de vil ikke undvære Riegels. Folkerådet henvender sig til regeringen 
i stærke ord, om at han má komme tilbage og indage en passende ærefuld og ansvarsfuld stilling, og det henvender sig ogsà til Riegels med bon om at vende tilbage. Riegels kommer, og bliver 3. medlem af det, der nu kaldes "Overbestyrelseskommissionen for Als og Ero m. m. Han bliver varmt modtaget, hvad folgende to vers af et hojtstemt velkomstdigt vidner om:

\section{Til Civilgouvernenren pan Sls,}

\section{Serr Rammerberre,}

Dberit v. IRiegels.

Nytaar 1849.

Fra Cimbrerż gamle Etranbe

Nu til yor $D$ e igien

Paa folverflare Bande

Dig bringer Sneffen ben:

Bi bille Dig meb (5labe,

3 Sjertets Sarmonie

Til Simlens t5ub yi bebe:

Dan vil beyare Dig!

3 Prosenz baarbe Dage

Du ileo, Syroe goo!

Til \$Den ber tilbage

Dyor for Din Bugge frob.

Beffotted' yore Ricere

Dloo Dyerfald og Gyig,

Du retbede yor 2 Ere!

Bi frole trygt paa Dig!

Affotograferet pã Sønderbory slot 
Hertugens ophold på Graasten i forbindelse med fællesregeringens antidanske indstilling bevirker, at hertugens tilhængere pá Als rejser hovedet og lader høre fra sig. Der kommer adresser til fællesregeringen og hertugen fra Nørherred med 36 underskrifter - fra Augustenborg med 75 - og en adresse fra Sønderborg by, med navne på flere prominente borgere, deriblandt et par byrâdsmedlemmer, og alle udtrykker de håbet om, at fællesregeringens myndighed også må udstrækkes til Als, og at hertugen snart mả vende tilbage til øen. Der er nu en ret livlig forbindelse mellem slesvigholstenerne her på øen og hertugen, så livlig, at der er tale om en efterretningstjeneste. Derfor ønsker folkerâdet al trafik mellem Als og Sundeved standset, undtagen færgen ved Sønderborg. Senere bliver der også en forbindelse ved Hardeshøj. Man er også meget opsat på at få underskriverne på de før omtalte adresser straffet, og de mest agressive udvist fra wen. Der sættes da ogsa en politiundersøgelse igang, men overbestyrelseskommissionen lader sagen dø hen, muligvis af frygt for, at fællesregeringen kunne finde på modaktioner mod dansksindede på fastlandet.

Riegels henvender sig igen i en chefsbefaling til landbevæbningen den 14. november 1849. Vel er landbevæbningen for tiden ude af alle tjenesteforhold som en naturlig følge af vábenstilstanden, men Hans Majestæt Kongen stoler trygt på, at hvis fjendtlighederne igen skulle begynde, de brave alsinger da med samme iver som ved krigens begyndelse ville møde under våben for at værge om vort kære Als. Derfor er det også nødvendigt, at vore våben holdes i den stand, at de er brugbare, når det behøves. Jeg tillader mig således at anmode Deres Velbårenhed om at opfordre respektive sognechefer i Nørreherredet at afholde et våbeneftersyn og hertil indsende disses rapporter, der måtte udvise $i$ hvilken tilstand geværerne og lædertøjet er befundne, hvormange deraf befinder sig i mandskabets værge, og hvor mange der findes hos sognecheferne som afleverede af det mandskab, der er udtrådte af bevæbningen og udskrevne til den stående hær. Jeg er overbevist om den iver og enighed, der især i fjor udmærkede landbevæbningen ved enhver lejlighed, også fremdeles vil gøre dem fortjent til det hæderlige omdømme, som såvel Hans Majestæt Kongen som hele Danmark har om alsingerne og deres landbevæbning, og da den kun han blive til varig hæder, når den hol- 
des til enden. Da vil alsingerne stedse nævnes som kongens tro mænd!

\section{Riegels.}

Bedes i afskrift meddelt samtlige sognechefer og af dem bekendtgjort for mandskabet. ${ }^{25}$

Hele denne aktivitet fra slesvig-holstenernes side gør, at folkerådet udvides med en repræsentantforsamling.

Der blev den 15. nov. afholdt et møde i Ketting kro, og man vedtog, at der $i$ sognene skulle valges $3-6$ mand, alt efter indbyggerantal, og denne landsforsamling « eller repræsentantforsamling skulle så danne et mellemled mellem beboerne og folkerådet. Vi ser, at der til denne repræsentantforsamling ikke alene vælges bønder, men også håndværkere, kådnere og innerster.

Et af de forste punkter på dagsordenen er også her det forhadte hoveri. Folkerådsmedlem H. C. Bladt skriver: „Degnen Bekker fra Lysabild var her for pá repræsentanternes vegne at aflægge en tak for, hvad jeg har gjort, og for min indstilling til regeringen og kongen om at blive fri for hoveri. Han udbad sig copierne af min indstilling, for at repræsentanterne bedre kunne følge sagens gange.

Den 2. jan. 1849 behandler man $i$ folkerådet et andragende til ministeriet om, at de værnepligtige på øen efter endt uddannelse i Sønderborg må overgå til landbevæbningen i stedet for til reserven, og der blev drøftet mange andre sager. Blandt andre også, at der måtte oprettes en højere bondeskole for Als, shvori den opvoksende ungdom kan erholde en tidssvarende oplysning og dannelse, så at den også $\mathrm{i}$ den henseende kan sideordnes de andre stænder og værdigt udfylde den stilling i samfundet, som hans stand fordrer". Dette andragende stilles også af Bladt. - Ved hans 50 års fødselsdag nedfælder han i sin dagbog nogle betragtninger og skriver bl. a. $\mathrm{m}$. h. t. sit valg til stænderforsamlingen: "Har du vist, at du blot nogenlunde kan repræsentere dette valgdistrikt overfor en højtbegavet skare af slesvig-holstensksindede stormænd? "Han har nok ofte på sin offentlige løbebane følt manglen på oplysning og dannelse, og nu vil han gøre sit til, at det ikke skal gå andre på samme måde.

Den 15. februar bliver der $i$ et folkerådsmøde bestemt, at der skal holdes møde den første tirsdag i hver måned, begyndende forst $i$ april. 
Efter våbenstilstandens ophør den 2. april var Als en eneste stor soldaterlejr - man forberedte en fremrykning på fastlandet, men efter et heldigt slag ved Ullerup stødte man mod stærk modstand af regulære tyske og prøjsiske tropper, og general Hansen trak de danske tropper tilbage igen - rømmede endog brohovedet, og for første gang fik alsingerne krigen at føle. Sønderborg var nu indenfor de tyske kanoners rækkevidde. Den 17. maj fik sønderborgerne en alvorlig forskrækkelse, idet der faldt et par granater i byen. Alvorligere var det den 6. juni og 7. og 8 . juni blev bønderne på Als beordret til at hente borgernes gods og indbo. Mange af Sønderborgs indbyggere, navnlig kvinder og børn, boede nu ude pâ Als, hvad der yderligere forværrede de i forvejen fortvivlede indkvarteringsforhold. Den 8 . juni måtte synsmændene afgive et skøn over, om det var muligt at forsyne de ventende russiske krigsskibe med vand fra østkysten af Als, og øens beboere følte sig nu i begivenhedernes brændpunkt.

Efterhånden faldt sindene dog lidt til ro, tropperne begynder at forlade øen og indskibes til Fyn og Jylland. Spændingen stiger igen, da man den 6. juli hører kanonerne tordne i nordvest, og da man senere erfarer resultatet af slaget ved Fredericia, er der stor glæde over sejren.

Den 10. juli er alsingerne stærkt optaget af det storslåede skue, da en russisk flådeafdeling, mest store tremastede krigsskibe, lå forankret mellem Als og Erø. Stormagterne er nu ved at gribe ind. - Blokaden af de prøjsiske Østersøhavne er ved at blive følelig, og striden mellem Prøjsen og det øvrige Tyskland tager til. Den 10. juli 1849 afsluttes igen en våbenstilstand.

Den 24. august festes der i Sønderborg for de svenske besættelsestropper, der senere besætter Flensborg og Åbenrå.

Under denne hektiske sommer har der ikke været tid og lejlighed til store afgørelser i folkerådet.

I november 1849 afløses overbestyrelseskommissionen for Als og Erø af bestyrelseskommissionen i Flensborg. Ved denne lejlighed bliver biskop J. Hansen uden indflydelse på øens forhold, og folkerådsmedlem $\mathrm{H}$. C. Bladt meddeler civilingeniør Riegels, at han nu vil forlade folkerådet til fordel for biskoppen. Dette tager Riegels ham imidlertid meget ilde op: "Vi må stå og falde sammen!l - Men Bladt går alligevel og beskæftiger sig fra nu af helt med hoveriafløsningen. 
Her kunne det måske være på sin plads at sige lidt om biskop Hansen. Hertugens tilhængere sagde ved lejlighed om ham, at han " seit Jahren bekannt " var »das Haupt der Insel «. I en lejlighedssang hedder det:

Political der gives visse strenge, som tảle ej det mindste dik! Om vi lod vor biskop leve lange, vi vidstnok en ulykke ikk $^{20}$

Det blev ilde optaget, når man udbragte et leve for biskoppen, når der var slesvig-holstenere til stede. Hertugen og biskop Hansen kendte hinanden. Hansen havde været præst i Notmark, som hørte under det augustenborgske distrikt, de var ofte stødt sammen, og som modstander var Hansen ikke til at kimse ad. Det fik de tysksindede at føle, da oprøret brød ud. Han stod fast, da andre vaklede, og hans rolige omdømme så alsingerne hen til med fortrøstning. Let bevægelige, som de er, kunne de måske i bevægede tider begejstres for Riegels og hans ildhu, men når det for alvor gjaldt, var det biskop Hansen, de henvendte sig til. Han var for alvor en af deres egne. Han vil dog ikke indtræde i folkerâdet i Bladts sted, fordi han kunne indse, at så længe Riegels skulle lede folkerådet, ville det ingen betydning få ${ }^{27}{ }^{27}$

Riegels vedblev dog at være formand for folkerådet, der nu bestod af ham og stadshauptmand Hanssen (Norsk), boelsmand Bonefeld, høker Matzen, H. C. Günthersohn, husfoged Riegels, Peter Møller, Hendrik Eriksen og proprietær Matzen på Melsgård.

Folkerådet samledes ikke ret ofte og havde tabt al indflydelse. Det ophørte uden dekret, efter at civilguvernementet blev ophævet i okt. 1850. Landbevæbningen opløstes ligeledes efter at have været stillet $i$ bero siden november 1849 . De regulære tropper, som i et antal på op imod 15000 var stationerede på øen, kunne nu let lose landbevæbningens opgaver.

Endnu den 14. 7. 1850 beder Riegels om en mand fra hvert bol i distriktet om at møde til skansearbejde på Dybbøl, alle med spade og skovl, for at foretage dette arbejde, som et talende bevis på, at den troskab og iver og gode ånd, der 1848 gav alsingerne navnkundighed, endnu besjæler dem, og at de ikke vil se vor retfærdige sag sejre, uden at have ydet deres bidrag til den sidste dag i krigen ${ }^{29}{ }^{2}$ 
Efter at Prøjsen er gået ud af krigen, er slesvig-holstenerne trukket sydpå og har fảet deres banesår i slaget ved Isted den 24.-25. juli, og nu skal Dybbølskanserne "vendes om " med front mod vest.

Dagen efter onsker ingeniorkaptajn Petersen de samme folk, »da de har arbejdet til hans fulde tilfredshed", for at få arbejdet fuldført.

9. 10. 1850 tilgår der følgende skrivelse til overinspektoratet:

I anledning af, at landbevæbningen på Als bortfalder, som følge af den almindelige værnepligts indførelse, har det behaget H. M. Kongen allernådigst at ophæve civilguvernementet for nævnte ø, samt Erø og allernådigst entledige kammerherre, oberst Riegels som civilguvernør for de nævnte øer.

Heltzen."

Landbevæbningens saga er dog ikke helt ude endnu. Den 10. december 1850 modtager den en skrivelse fra kongen:

Vor krigsminister har $\mathrm{i}$ anledning af, at landbevæbningen på Als ved indførelsen af almindelig værnepligt nu bortfalder, henledet vor allerhøjeste opmærksomhed på den af væbningen under krigen ydede gode tjeneste og navnlig fremhævet, at den ånd, der har besjælet såvel de kommanderende som mandskabet, har bidraget til at sikre denne for de militære operationer under de forløbne 3 års felttog så vigtige ø.

Ligesom vi selv personlig ofte har haft lejlighed til at overbevise os om den $\mathrm{i}$ væbningen herskeņde gode ånd, således har det været os særdeles kært at modtage forannævnte beretning.

Vi finder os derfor opfordret til at tilkendegive såvel de kommanderende $i$ særdeleshed som samtlige medlemmer $i$ almindelighed vor allerhøjeste tilfredshed og tak for deres under krigen udviste iver og virksomhed for vor og landets fælles sag.

Befalende eder Gud!

Givet på vort slot Christiansborg, den 10. oktober 1850.

Frederik $R^{30}$

Pr. Riegels til landbevæbningen på Als.

Efter al sandsynlighed har Runacker modtaget en lignende skrivelse, og de to kommandører har videresendt den til deres 
sognechefer i Nørre- og Sønderherred, der har oplæst den ved kirken den næstfølgende søndag.

Med denne skrivelse fra allerhøjeste sted er et interessant og spændende, men også et ærefuldt kapitel af øens historie afsluttet.

\section{NOTER}

Ovenstående fremstilling bygger væsentligst på dagbøger og optegnelser, der findes på Als. Hvor den historiske sammenhæng gjorde det onskeligt, er der brugt materiale fra Landsarkivet i Ảbenrá. Jeg er vel vidende om, at arkivalier i Rigsarkivet ville have givet vigtige oplysninger. Dem vil man kunne finde $\mathrm{i}$ Holger Hjelholts bog: Sønderjylland under Treårskrigen, der udkom ved den tid, da jeg havde indsamlet det hjemlige kildemateriale og omtrent havde afsluttet bearbejdelsen af det. Jeg har brugt:

Stænderdeputeret H. C. Bladts dagbog (i privat eje).

Biskop Jørgen Hansens optegnelser, som de findes skrevet tværs over rubrikkerne i en kirkebog (Landsarkivet i Åbenrå).

Pastor Chr. Knudsen: Samlinger til en familiehistorie ved H. H. Jessen, Pebersbjerg.

Peter Schmidt, Lavensbymark: optegnelser (i privat eje).

Claus Madsen, Holm, optegnelser tilhørende Hans Clausen, Elsmark. Claus Madsen var boelsmand og sognechef i Holm. Optegnelserne er foretaget $i$ et stilehefte.

Billedmaterialet er samlet på museet på Sønderborg slot, fotograf Chr. Petersen, Sønderborg.

1. I $\gg$ Bogen om Als $\star$.

2. Biskop J. Hansen.

3. P. Schmidt.

4. Pastor Chr. Knudsen.

5. Biskop J. Hansen.

6. H. C. Bladt.

7. P. Schmidt.

8. H. C. Bladt, biskop J. Hansen, pastor Chr. Knudsen,

9. Biskop J. Hansen.

10. Pastor Chr. Knudsen.

11. H. C. Bladt.

12. Pastor Chr. Knudsen.

13. LA, Ảbenrå.

14. LA, Ảbenrå.

15. LA, Ảbenrå.

16. LA, Ảbenrå.

17. Biskop J. Hansen.

18. Biskop J. Hansen. 
19. Biskop J. Hansen.

20. Biskop J. Hansen.

21. LA, Åbenrå.

22. LA, Ảbenrå.

23. Claus Madsen.

24. H. C. Bladt.

25. Claus Madsen.

26. LA, Åbenrå.

27. H. C. Bladt.

28. LA, Ảbenrå.

29. LA, Åbenrå.

30. Claus Madsen.

Om brødrene Hans Christian Riegels og Jacob Friedrich Wilhelm Riegels kan følgende oplyses på grundlag af: Slægten Riegels gennem 300 år af $\mathrm{C}$. W. O. Riegels.

Hans Christian Riegels, født 7. februar 1793 på Fægteborg ved Nørborg, død 9. januar 1861 .

15. marts 1848 udnævnt til kammerherre, samme år til oberst.

Sclt. i infanteriet 1808. Prmlt. 1810. Stabskapt. 1822. Komp.chef 1829. Land- og søkrigskommissær 1835. Generalkrigskommissær fra 1838.

I Treårskrigen blev han 1848 først udnævnt til kommandant over Als, og kort efter til civilguvernør over Als (og Erø) til 1850. 1852 blev han folketingsmand i Ribe amts 4 . kreds. 1857 klitinspektør. Afsked som oberst efter ansøgning 3. okt. 1850. Proprietær. Ejede først Sønderbygaard i Vejle amt og købte 1839 den smukke lystejendom »Snoghøj» ved Fredericia og fik dermed embedet som postmester og privilegium på hele færgefarten mellem Jylland og Fyn.

Dekorationer: Ridder af Dannebrog 1828. Kommandør af Dannebrog 1856. Dannebrogsmand 1848. Ridder af St. Annaordenen II. 1851. Den franske St. Helenamedaille 1858. Oprettede Snoghøj planteskole med læreanstalt for gartnere. 1843 stiftede han: Det praktiske haveselskab for Jylland, Fyn og hertugdømmet Slesvig. Udfoldede en livlig virksomhed til træplantningens og havedyrkningens fremme, skrev om skolevæsen, nationalfølelse og folkeoplysning.

C. H. Riegels var en af pionerne for beplantning af heder og klitter.

Broder til nedennæunte Friedrich Wilhelm Riegels.

(Jacob) Friedrich Wilhelm Riegels, født 20. maj 1799, død 11. sept. 1869.

Gik først officersvejen. Landkadet 1812. Sekondløjtnant 1817. Prmlt. i H. M. Kongens livregiment 1825.

Afløste sin far som husfoged for Als Nørherred 1826 indtil 1864, da han blev fordrevet af tyskerne. Var desuden retsskriver for Als Søn- 
derherred. Udnævnt først til krigsråd senere til justitsråd. Købte gården Fægteborg 1828 af sin fader. Ejede slægtens lyst til havedyrkning og skovplantning, udvidede den store have, hans fader havde anlagt ved Fægteborg. Anlagde og beplantede den smukke lystskov Egelund . Som arbejdskraft benyttede han arrestanter, der sorterede under hans embede.

Husfoged: For 1864 i Slesvig og Holsten benævnelsen på en i reglen kgl. udnævnt embedsmand, der havde overopsyn med vejene og skovene $\mathrm{i}$ sin embedskreds med de offentlige bygninger og ægtkørselsvæsnet, ligesom han ogsi deltog i udskrivningsforretninger og skovauktioner.

E. C. 